\title{
IMPLEMENTING GLOBAL STRATEGY IN THE UAE FOREIGN AID: FROM ARAB SOLIDARITY TO SOUTH-SOUTH COOPERATION
}

\author{
K. Almezaini \\ Zayed University, Abu Dhabi, United Arab Emirates \\ University of Cambridge, Cambridge, UK
}

\begin{abstract}
This article is dedicated to the phenomenon of the "emerging donors" activity within the South - South cooperation (SSC). The case of the United Arab Emirates (UAE) foreign aid demonstrates new principles and instruments of SSC; first of all it is solidarity and engagement with the UN and other governmental and non-governmental aid organizations to contribute to the development of the Global South countries. The visibility of the UAE at the regional (Middle East) and international level led the country to contribute to all types of aid activities, particularly humanitarian efforts. As a matter of fact, the UAE is a 'humanitarian nation', where aid has become part of its daily foreign policy activities. Consequently, its relations with countries in the "South" and developing countries became much stronger due to the fact that it has contributed to their economic developments and humanitarian efforts. South—South cooperation includes transfer of technologies and resources between the developing countries.

Using predominantly quantitative methodology the author analyses the UAE strategy of the foreign aid and proves its coherence with the Sustainable Development Goals (SDGs) and Millennium Development Goals (MDGs) of the United Nations. Moreover, the author shows the extension of the UAE foreign aid "map": largest aid recipient for the UAE are mainly in Asia and Africa where the poorest countries in the world exist.
\end{abstract}

Key words: the United Arab Emirates (UAE), South-South cooperation (SSC), foreign aid, the Middle East, Sustainable Development Goals (SDGs), Millennium Development Goals (MDGs), Arab aid

The United Arab Emirates (UAE) transformed its foreign aid since 1970's to be among the leading and largest aid donors in the world in relation to its Gross Domestic Product (GDP). Due to foreign aid and branding strategies, it became more visible than ever.

The active role of the UAE in the South-South cooperation reflects the fact that it has gone beyond the responsibilities only towards countries who share with it language, culture, history and religion to include all other countries that are in needed. This transformation led the Emirates to engage with the UN efforts in tackling poverty in countries in the South as well as countries that have poor economic development. In 2016, the UAE hosted the first Global South-South Development Expo (GSSD Expo). The GSSD Expo is a unique platform that the UN system offers solely for the global South [South-South and Triangular... 2016]. It provides an opportunity for all development actors and stakeholders to showcase Southern development solutions, celebrate South - South and triangular cooperation (SSTC) successes, share knowledge and hard-earned experience, explore new avenues for collaboration, and initiate new partnerships [South-South and Triangular... 2016]. The UAE's role within the SSC might best be seen from the 'solidarity' perspective. Before the establishment of SSC agenda, the UAE main regional aid was perceived and seen as a solidarity aid despite some criticism. Regional instabilities in the Middle East and North Africa (MENA) 
region forced regional aid donors such as the UAE to alter their priorities to support stabilities. Yet, this shift towards the region led to the rising number of aid donors and competition between regional and international donors.

Since the formation of the UAE, aid institutions have developed significantly ranging from ministries to bureaus that monitor and report aid. In particularly, the past ten years the UAE began providing full and detailed aid reports that made it to become part of many organizations such as OECD in 2014. This change in UAE institutional framework encouraged the state to engage at the international level to become a responsible donor particularly in the issues for development, humanitarian aid and South-South cooperation.

Therefore, this paper seeks to examine the role of the UAE within the context of the Buenos Aires Plan of Action and South-South cooperation. In addition, it asks two main questions, what explains the rising role of the UAE in the support of the countries in the South? What role the UAE has played in the promotion and support of the South-South cooperation? The paper consists of two main sections; first section looks at the definition and geographical scope of South-South cooperation that comes as part of Buenos Aires Plan of Action within the context of Arab aid; and second examines the rising role of the UAE in support of countries in the South. Due to the limitation of this study, uses both quantitative and qualitative but relies mainly on secondary sources. Statistics data are taken mainly from private and governmental sources. The dependence on governmental reports is due to the absence of private statistics or studies that provide sufficient accurate statistics.

There is hardly any study that has focused merely on Arab Global South relations. However, studies on relations between Arab donors and countries of the Global South have focused mainly on Africa. Yet, there are good number of studies to have focused on the political and economic relations between Arab and other developing countries. This is because the majority of Arab aid goes mainly to Arab and some Muslim countries. Amongst the most important studies is by Robert Mertz and Pamela Mertz [Mertz, Mertz 1983]. The study looks at both the bilateral and multilateral aid from Arab donors which include the UAE, Kuwait, Algeria, Saudi Arabia, Qatar and Libya. In addition, it examines the motives and objectives of Arab aid. Mainly it looks at both the role of Islam and politics in the orientation of aid. Although the section on the UAE is brief, but it provides interesting analysis of how the UAE have managed to provide good amount of aid to Sub-Saharan Africa. The study, however, does not look at the 'SouthSouth cooperation' dimension, rather on how Arab donors have contributed to SubSaharan Africa.

In addition, M. Rouis' study [Rouis 2010] provides some interesting analysis of the role of Arab countries in the South-South cooperation. Although there is no particular section examines this, the author stresses the fact that Arab donors through multilateral institutions emphasis on fostering South-South cooperation by involving technical advisers from developing member countries and by twinning institutions across member countries [Rouis 2010]. He adds that South-South cooperation is one of the hallmarks of Arab aid, and its effectiveness and lessons merit careful study [Rouis 2010]. In addition, Neumayer's study [Neumayer 2003] examines the determinants of Arab aid but focuses on Arab solidarity. This can be seen as cooperation with developing countries in the Middle East. However, he does not examine South—South 
cooperation. Overall, most studies look at South-South cooperation from a multilateral aid perspective but not bilaterally. This is because Arab aid is known to be mostly bilateral. Therefore, this study seeks to fill the gap for the case of the UAE and its role in the South-South cooperation ${ }^{1}$.

\section{SOUTH-SOUTH COOPERATION}

Countries in the Global South are those who are considered from the "developing countries'. According to UNOSSC, "the term "South" or "Global South" refers to developing countries, which are located primarily in the Southern Hemisphere; The Global South includes Asia (with the exception of Japan, Hong Kong, Macau, Singapore, South Korea and Taiwan), Central America, South America, Mexico, Africa, and the Middle East (with the exception of Israel)" [South-South and Triangular... 2016].

This term, however, has not yet been updated. This is due to the fact that there are countries in the Southern Hemisphere who have higher GDP per capita than many developed nations such as Qatar, the UAE, Saudi Arabia and Kuwait. The measurement and factor to indicate countries that are from developing or developed should certainly be revisited. The Gulf states have developed from being aid recipient in the 1950's to become aid donors and having higher GDP per capita than many countries in the Northern Hemisphere. Those countries have developed relatively strong economies, even if some are considered rentier states. However, for the purpose of this study, below is a brief definition and analysis of South-South cooperation.

Table 1

Top 22 GDP per capita

\begin{tabular}{|c|l|c|c|}
\hline RANK & \multicolumn{1}{|c|}{ COUNTRY } & GDP PER CAPITA (PPP) & DATE OF INFORMATION \\
\hline 1 & Liechtenstein & $\$ 139,100$ & 2009 EST. \\
\hline 2 & Qatar & $\$ 124,500$ & 2017 EST. \\
\hline 3 & Monaco & $\$ 115,700$ & 2015 EST. \\
\hline 4 & Macau & $\$ 111,600$ & 2017 EST. \\
\hline 5 & Luxembourg & $\$ 106,300$ & 2017 EST. \\
\hline 6 & Bermuda & $\$ 99,400$ & 2016 EST. \\
\hline 7 & Singapore & $\$ 93,900$ & 2017 EST. \\
\hline 8 & Isle Of Man & $\$ 84,600$ & 2014 EST. \\
\hline 9 & Brunei & $\$ 78,200$ & 2017 EST. \\
\hline 10 & Ireland & $\$ 75,500$ & 2017 EST. \\
\hline 11 & Norway & $\$ 71,800$ & 2017 EST. \\
\hline 12 & Falkland Islands (Islas Malvinas) & $\$ 70,800$ & 2015 EST. \\
\hline 13 & United Arab Emirates & $\$ 67,700$ & 2017 EST. \\
\hline 14 & Sint Maarten & $\$ 66,800$ & 2014 EST. \\
\hline 15 & Kuwait & $\$ 66,200$ & 2017 EST. \\
\hline 16 & Gibraltar & $\$ 61,700$ & 2014 EST. \\
\hline 17 & Hong Kong & $\$ 61,400$ & 2017 EST. \\
\hline 18 & Switzerland & $\$ 61,400$ & 2017 EST. \\
\hline 19 & United States & $\$ 59,500$ & 2017 EST. \\
\hline 20 & San Marino & $\$ 58,600$ & 2017 EST. \\
\hline 21 & Jersey & $\$ 56,600$ & 2016 EST. \\
\hline 22 & Saudi Arabia & $\$ 54,800$ & 2017 EST. \\
\hline
\end{tabular}

Country Comparison: GDP - Per Capita (PPP).

Source: Central Intelligence Agency. URL: https://www.cia.gov/Library/publications/the-world-factbook/ rankorder/2004rank.html (accessed 13.06.2018).

1 These are some of the studies that looked in general at aid from Arab countries to developing countries: [Merz, Merz 1983; Rouis 2010; Law 1978; Al-Zayed 2012; El Mallakh, Kadhim 1976; Almezaini 2012; Shushan, Marcoux 2011; Van den Boogaerde 1991; Hunter 1984; Shihata 1982]. 
According to United Nation Office for South-South Cooperation (UNOSSC), "South-South cooperation is a broad framework for collaboration among countries of the South in the political, economic, social, cultural, environmental and technical domains. Involving two or more developing countries, it can take place on a bilateral, regional, subregional or interregional basis. Developing countries share knowledge, skills, expertise and resources to meet their development goals through concerted efforts. Recent developments in South-South cooperation have taken the form of increased volume of South-South trade, South-South flows of foreign direct investment, movements towards regional integration, technology transfers, sharing of solutions and experts, and other forms of exchanges" [South-South and Triangular... 2016].

Furthermore, SSC seek to achieve wide range of objectives which include the following:

- foster the self-reliance of developing countries by enhancing their creative capacity to find solutions to their development problems in keeping with their own aspirations, values and special needs;

— promote and strengthen collective self-reliance among developing countries through the exchange of experiences; the pooling, sharing and use of their technical and other resources; and the development of their complementary capacities;

- strengthen the capacity of developing countries to identify and analyse together their main development issues and formulate the requisite strategies to address them;

- increase the quantity and enhance the quality of international development cooperation through the pooling of capacities to improve the effectiveness of the resources devoted to such cooperation;

- create and strengthen existing technological capacities in the developing countries in order to improve the effectiveness with which such capacities are used and to improve the capacity of developing countries to absorb and adapt technology and skills to meet their specific developmental needs;

— increase and improve communications among developing countries, leading to a greater awareness of common problems and wider access to available knowledge and experience as well as the creation of new knowledge in tackling development problems;

- recognize and respond to the problems and requirements of the least developed countries, land-locked developing countries, small island developing states and the countries most seriously affected by, for example, natural disasters and other crises; and

- enable developing countries to achieve a greater degree of participation in international economic activities and to expand international cooperation for development [South-South and Triangular... 2016].

In other words, it means the exchange of all type of resources and technologies between countries sharing development problems. Despite that this initiative seeks for cooperation between countries of the South, yet there are only limited donors capable of providing support. Those donors such as China, Brazil, Gulf States, etc. do not have clear mechanism of exchanging resources and technology with countries in the Global South. This requires further cooperation, and the SSC here play significant role in promoting the emerging donors in the global political economy. Quadir points out that 
although many non-Development Assistance Committee (DAC) countries do not report their flow of aid to the Organization of Economic Cooperation and Development (OECD), a recent OECD study confirms that non-traditional lending countries, including Turkey, Saudi Arabia, Kuwait, Israel, the Czech Republic, Thailand and the United Arab Emirates, have stepped up their efforts to play a more prominent role in development cooperation in the past several years [Quadir 2013].

Gulf donors which include the UAE, Kuwait, Saudi Arabia and Qatar have long history of aid despite they are considered from developing countries and emerging donors. They have started cooperation with countries in developing countries before the establishment of Buenos Aires Plan of Action in 1978. They have established special funds to support their fellow Arab countries, and countries in Africa, for example, the Arab Fund for Economic and Social Development and Arab Bank for Economic Development in Africa. This is for many objectives but mainly solidarity with developing nations.

\section{THE UAE AND SOUTH-SOUTH COOPERATION}

The UAE is considered among the leading countries in supporting the initiative of SSC. Initially, regional factors in the Middle East such as Arab nationalism, religion and identities played significant guiding role in the orientation of the UAE aid. In particular, Arab solidarity constituted a major dimension. Gerd Nonneman points out that "indeed, South - South cooperation has been realized in the Middle East, particularly regarding Arab solidarity" [Nonneman 1988]. This Arab solidarity, despite still being an important factor, the UAE emerging international image as a global aid donor encouraged it to include all developing countries. This was evident in the UAE's establishment of the Ministry of International Cooperation and Development in 2013 which has been dissolved later to be part of the Ministry of Foreign Affairs and International Cooperation.

In 2016, as the role of the UAE in the Global South was growing, it has hosted the annual Global South-South Development Expo (GSSD Expo). In fact, it was the first ever GSSD Expo to be hosted by a member state since its establishment in 2008 . This is due to the beliefs of the UAE leadership in maintaining its international role in supporting developing countries. According to the UAE SDGs report, "this was the first ever GSSD Expo hosted by a Member State. Thanks to His Highness Sheikh Khalifa bin Zayed Al Nahyan, President of the United Arab Emirates, and His Highness Sheikh Mohammed bin Rashid Al Maktoum, Vice-President, Prime Minister and Ruler of Dubai, and Patron of the Zayed International Foundation for the Environment, for the exceptional leadership and generous support to the GSSD Expo 2016. This special edition of South - South in Action is a compilation of not only success stories created in the UAE, but of all the stories shared by Member States and partner institutions during GSSD Expo 2016" [UAE and the 2030... 2017].

According to UNOSSC, this special edition of South-South in Action is a compilation of not only success stories created in the UAE, but of all the stories shared by Member States and partner institutions during GSSD Expo 2016 [South — South and Triangular... 2016]. In addition, the UNOSSC points out that the institutional contribution 
of the Government of the United Arab Emirates through the Zayed International Foundation for the Environment has provided invaluable support to our ongoing efforts to build a global partnership for sustainable development that leverages the effectiveness of Southern development solutions and highlights the progress that countries of the South have made in addressing and overcoming the challenges that they face [South-South and Triangular... 2016]. This reflects the engaging role of the UAE at the Global level. Furthermore, Dr. Zeyoudi demonstrates that over the past years, the UAE has strengthened its role in international cooperation, especially with the South, launching global initiatives focused on vital sectors such as education, health, water, energy and capacity building [South-South and Triangular... 2016].

Furthermore, and in line with the Sustainable Development Goals (SDGs), the UAE has committed itself not only to participate in helping counties but also initiated programs that meet the SDGs. In 2016, MOFAIC launched the UAE Foreign Assistance Policy the nation's long-term development cooperation plan towards eradicating poverty and promoting global peace and prosperity [UAE Foreign Aid... 2017]. Within the context of SSD, the UAE played an active role in the transition from the MDGs to SDGs by participating in various high-level discussion on the formation of the SDGs [UAE Foreign Aid... 2017]. All of the SDGs are in fact objectives that seek to provide support particularly to countries in the Global South who mainly suffer from poverty, lack of health services, poor education, inequality, etc. Therefore, in $201676 \%$ of the UAE foreign assistance supported the eight SDGs highlighted in the UAE Foreign Assistance Policy [UAE Foreign Aid... 2017]. Furthermore, according to the UAE foreign aid report, "in 2016, the first year of the implementation of the 15-year SDGs, the UAE quantified its efforts towards each of the 17 goals that contribute to global poverty eradication and sustainable development. This support corresponds to AED 22.23 billion (USD 6.05 billion) in foreign aid disbursements" [UAE Foreign Aid... 2017]. In addition, it stated that the UAE's top three supported SDGs in 2016 - SDG 1 (No Poverty), SDG 8 (Decent Work and Economic Growth), and SDG 17 (Partnerships for the Goals) accounted for nearly $70 \%$ of the total [UAE Foreign Aid... 2017].

Therefore, the engagement of the UAE with SSD and SDGs reflects the continuing development of the UAE aid from a regionally focused to be side by side with and its proving international aid donors. This has encouraged the Emirates to initiate various domestic policies. It has created a special portal for the UAE's dedication for the support and implementation of the SDGs. It monitors and shows all the activities of governmental and non-governmental aid agencies in the UAE that goes in line in achieving the SDGs ${ }^{2}$. Furthermore, in 2017 it has established a National Committee on Sustainable Development Goals. According to the first report by the Committee, "a national implementation plan is a strategy for how SDGs will align with a country's development agenda and how policy implementation will be prioritized and embedded within a government's policy decision-making and statistical reporting processes" [UAE and the $2030 \ldots$ 2017]. The two figures below show the UAE's timeline of the development towards SDGs and the UAE's distribution of aid based on these goals.

${ }^{2}$ For further information about this portal visit URL: www.uaesdgs.ae (accessed 13.06.2018). 


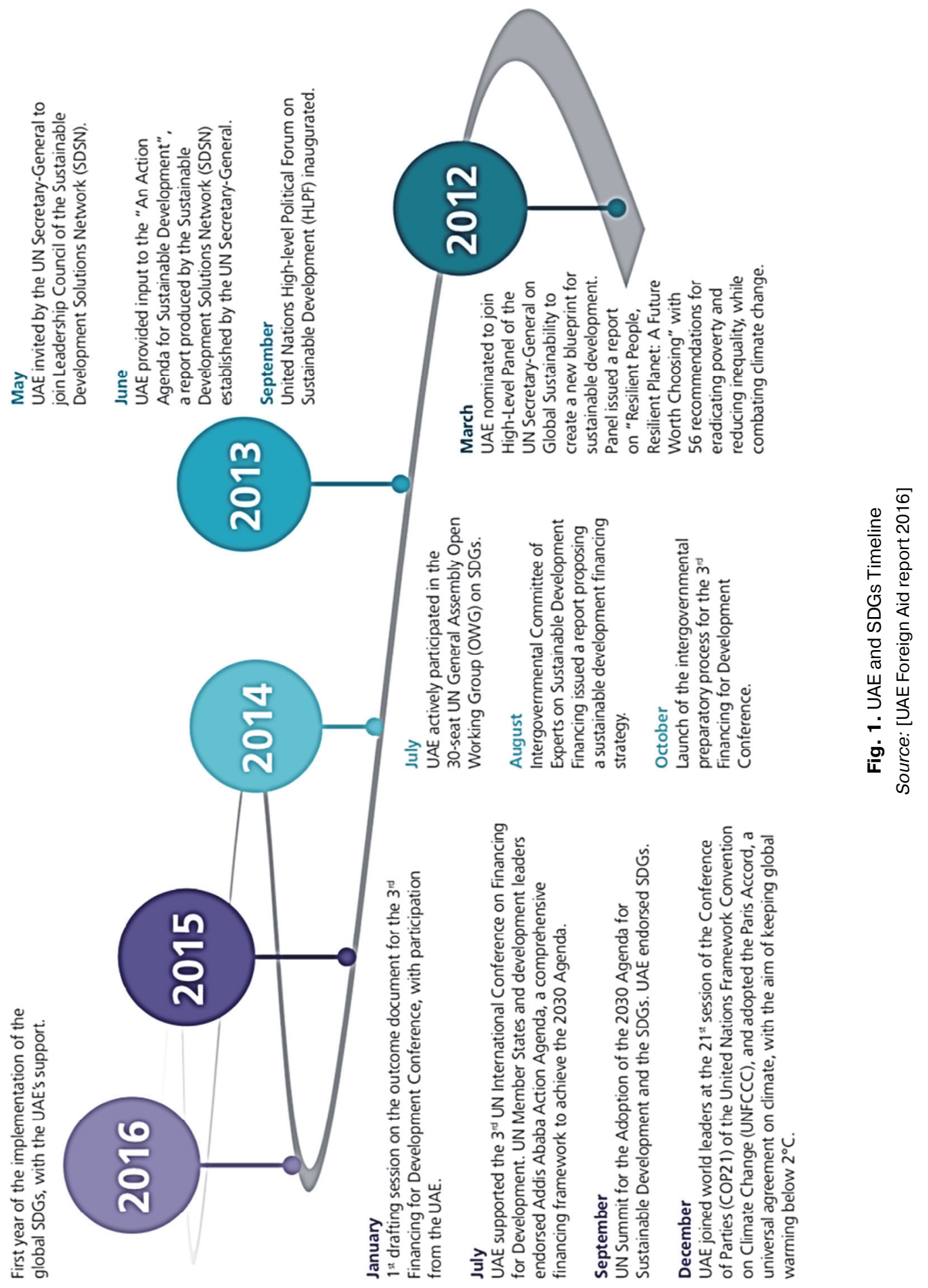


However, what explains the UAE's rising role in supporting countries of the Global South and SSC? There is great number of factors that led the UAE to adapt this role, but mainly to one main factor: Solidarity.

\section{SOLIDARITY}

The International Federation of Red Cross (IFRC) is attempting to build on these concepts of solidarity, which act as important drivers of public support for international assistance, beyond neighbourhood and brotherhood to humanity as a whole, so that the forms of solidarity become more and more universal in supporting those in need [Cotterrell, Harmer 2005]. This is certainly shared with the UAE's leadership. According to the UAE Foreign Aid Report, the Vice-President His Highness Sheikh Mohammed Bin Rashid Al Maktoum stated: "Our nation believes in the importance of solidarity and synergy among all countries of the world, and we are keen to make the UAE an active and effective member in the international community through channelling its foreign aid to the global thematic priorities identified by the international development and relief organizations, which are consistent with the development goals of fighting poverty, ignorance and illness" [UAE Foreign Aid... 2017]. Solidarity was evident in the UAE's objectives and orientation of aid since 1970's, even it has fluctuated due to the changing dynamics in the Middle East and the world.

Solidarity with countries in the Middle East and other developing countries have been playing a major role in the orientation of the UAE aid. During the early years, countries that faced similar security threats, recognized the UAE's existence and accepted to side with the UAE. This included countries that share language and religion with the UAE, as well as countries in Africa that have different languages and religions. It was a sign of the emergence of the 'solidarity' dimension in the UAE aid despite some criticism. For the UAE RCS, the guiding idea is that "charitable donations must be free of any ulterior purposes or intent and given simply because there is a need and an obligation to share the suffering of others as part of our own humanity. This begins with our own country, then neighbours, and widens outwards" [Cotterrell, Harmer 2005]. The UN and main international aid organization seek to encourage all donors to consider 'solidarity' as their main driver to assist other nations. As the table shows, largest aid recipient for the UAE are mainly in Asia and Africa where the poorest countries in the world exist.

Table 2

Top 25 Countries of UAE Funds Disbursed (In AED millions, 2013)

\begin{tabular}{|l|c|}
\hline \multicolumn{1}{|c|}{ Country } & Amount \\
\hline Egypt & $16,990.94$ \\
\hline Jordan & 582.93 \\
\hline Pakistan & 546.54 \\
\hline Afghanistan & 431.46 \\
\hline Palestine & 340.07 \\
\hline Morocco & 295.85 \\
\hline Yemen & 272.7 \\
\hline Algeria & 193.67 \\
\hline Lebanon & 176.96 \\
\hline Albania & 108.59 \\
\hline
\end{tabular}




\section{End of the table 3}

\begin{tabular}{|l|l|}
\hline \multicolumn{1}{|c|}{ Country } & \\
\hline Somalia & 92.32 \\
\hline Guinea & 75.67 \\
\hline Sudan & 64.74 \\
\hline Indonesia & 49.92 \\
\hline India & 41.49 \\
\hline Ethiopia & 40.47 \\
\hline Azerbaijan & 36.87 \\
\hline Tanzania & 34.74 \\
\hline Seychelles & 29.86 \\
\hline Kazakhstan & 26 \\
\hline Uganda & 25.43 \\
\hline Mauritania & 23.84 \\
\hline Mali & 23.76 \\
\hline Iraq & 22.8 \\
\hline Gambia & 21.94 \\
\hline
\end{tabular}

Source: UAE Foreign Aid Mini Report $2013^{3}$.

Distribution of UAE aid 2014-2016 (in USD millions, and as \% of total)

\begin{tabular}{|c|c|c|c|c|c|c|}
\hline \multirow{2}{*}{$\begin{array}{c}\text { Continent / } \\
\text { Assistance } \\
\text { Category }\end{array}$} & \multicolumn{2}{|c|}{2014} & \multicolumn{2}{|c|}{2015} & \multicolumn{2}{|c|}{2016} \\
\hline & $\begin{array}{c}\text { Foreign } \\
\text { Assistance } \\
\text { USD million }\end{array}$ & Percentage & $\begin{array}{c}\text { Foreign } \\
\text { Assistance } \\
\text { USD million }\end{array}$ & Percentage & $\begin{array}{c}\text { Foreign } \\
\text { Assistance } \\
\text { USD million }\end{array}$ & Percentage \\
\hline Africa & $3,995.4$ & $65 \%$ & $6,838.7$ & $78 \%$ & $3,468.8$ & $57 \%$ \\
\hline Development & $3,826.2$ & $62 \%$ & $6,707.9$ & $76 \%$ & $3,304.4$ & $55 \%$ \\
\hline Charity & 80.8 & $1 \%$ & 44.1 & $0.5 \%$ & 65.7 & $1 \%$ \\
\hline Humanitarian & 88.4 & $1 \%$ & 86.7 & $1 \%$ & 62.7 & $1 \%$ \\
\hline Asia & 1,392.9 & $23 \%$ & $1,805.8$ & $21 \%$ & $2,036.6$ & $34 \%$ \\
\hline Development & 758.5 & $12 \%$ & $1,196.3$ & $14 \%$ & $1,546.3$ & $26 \%$ \\
\hline Humanitarian & 553.8 & $9 \%$ & 549.0 & $6 \%$ & 427.2 & $7 \%$ \\
\hline Charity & 80.6 & $1 \%$ & 60.5 & $0.7 \%$ & 63.1 & $1 \%$ \\
\hline Global & 226.5 & $4 \%$ & 87.4 & $1 \%$ & 293.5 & $5 \%$ \\
\hline Development & 211.9 & $3 \%$ & $73 / 6$ & $0.8 \%$ & 269.9 & $4 \%$ \\
\hline Humanitarian & 11.0 & $0.2 \%$ & 10.3 & $0.1 \%$ & 23.6 & $0.4 \%$ \\
\hline Charity & 3.6 & $0.1 \%$ & 3.5 & $0.04 \%$ & 0 & $0.0 \%$ \\
\hline Europe & 538.3 & $9 \%$ & 44.2 & $0.5 \%$ & 243.9 & $4 \%$ \\
\hline Development & 516.8 & $8 \%$ & 36.7 & $0.4 \%$ & 229.8 & $3.8 \%$ \\
\hline Charity & 15.8 & $0.3 \%$ & 7.5 & $0.1 \%$ & 9.4 & $0.2 \%$ \\
\hline Humanitarian & 5.7 & $0.1 \%$ & 0.1 & $0.001 \%$ & 4.7 & $0.1 \%$ \\
\hline Americas & 1.8 & $0.03 \%$ & 1.7 & $0.02 \%$ & 4.8 & $0.1 \%$ \\
\hline Development & 0.3 & $0.01 \%$ & 0.6 & $0.01 \%$ & 3.3 & $0.1 \%$ \\
\hline Charity & 1.5 & $0.02 \%$ & 1.1 & $0.01 \%$ & 1.5 & $0.02 \%$ \\
\hline Humanitarian & 0.01 & $0.0002 \%$ & 0 & $0.0 \%$ & 0 & $0.0 \%$ \\
\hline Oceania & 9.8 & $0.2 \%$ & 26.4 & $0.3 \%$ & 4.1 & $0.1 \%$ \\
\hline Development & 9.6 & $0.2 \%$ & 26.1 & $0.3 \%$ & 4.0 & $0.1 \%$ \\
\hline Charity & 0.2 & $0.003 \%$ & 0.1 & $0.001 \%$ & 0.1 & $0.002 \%$ \\
\hline Humanitarian & 0.01 & $0.0002 \%$ & 0.3 & $0.003 \%$ & 0 & $0.0 \%$ \\
\hline Grand Total & $6,164.7$ & $100 \%$ & $8,804.3$ & $100 \%$ & $6,051.7$ & $100 \%$ \\
\hline
\end{tabular}

Source: UAE Foreign Aid Report $2016^{4}$.

3 UAE Foreign AID. URL: https://www.mofa.gov.ae/EN/TheMinistry/UAEForeignPolicy/Pages/ UAEFAR.aspx (accessed 13.06.2018).

4 Ibid. 
During the early years of the Emirates, development aid focused mainly on countries that share with the UAE similar developmental issues as well as history, language, religion and culture. This has included all Arab countries, where the UAE with all major Arab donors established the Arab Fund for Economic and Social Development (AFESD). This has played significant role in supporting Arab developing countries. According to the AFESD, "the principal purpose of the Arab Fund is to contribute to the financing of economic and social development projects in the Arab countries. To attain this purpose, the Arab Fund provides financing for economic development projects by extending loans, on concessionary terms, to governments and public corporations and enterprises of member states, giving preference to projects which are vital to the Arab World and joint Arab projects. It serves as a catalyst for encouraging the investment, directly or indirectly, of public and private capital in a manner conducive to the development of the Arab economy and provides expertise and technical support in the various spheres of economic development" [Purpose of the Fund 2017c].

Table 4

Distribution of UAE funds in 2009 , by region

\begin{tabular}{|c|c|}
\hline \multicolumn{1}{|c|}{ Region } & Total Contributed (AED) \\
\hline Africa & $911,136,730$ \\
\hline North Africa & $245,869,511$ \\
\hline Sub-Saharan Africa & $665,057,219$ \\
\hline Unspecified & 210,000 \\
\hline Americas & $156,227,931$ \\
\hline Central America & 501,355 \\
\hline North America & $155,366,576$ \\
\hline South America & 360,000 \\
\hline Asia & $7,774,766,070$ \\
\hline Far East & $63,196,226$ \\
\hline Middle East & $4,659,828,768$ \\
\hline South \& Central Asia & $3,051,741,076$ \\
\hline Europe & $45,225,062$ \\
\hline Oceania & 371,875 \\
\hline Multilateral & $26,510,087$ \\
\hline Unspecified & $19,373,183$ \\
\hline Grand Total & $\mathbf{8 , 9 3 3 , 6 1 0 , 9 3 8}$ \\
\hline
\end{tabular}

Source: UAE Foreign Aid Report $2009^{5}$.

Table 5

Disbursements of UAE ODA, by region and country (2013)

\begin{tabular}{|c|c|c|}
\hline Region / Country & AED & USD \\
\hline North Africa & $\mathbf{2 8 , 4 5 1 , 4 2 5 , 3 0 0}$ & $\mathbf{7 , 7 4 6 , 1 0 0 , 0 0 0}$ \\
\hline Egypt & $22,757,908,000$ & $6,196,000,000$ \\
\hline Morocco & $4,609,615,000$ & $1,255,000,000$ \\
\hline Algeria & $1,083,902,300$ & $295,100,000$ \\
\hline West Africa & $\mathbf{1 1 0 , 1 9 0 , 0 0 0}$ & $\mathbf{3 0 , 0 0 0 , 0 0 0}$ \\
\hline Mauritania & $110,190,000$ & $30,000,000$ \\
\hline East Africa & $\mathbf{3 6 , 7 3 0 , 0 0 0}$ & $\mathbf{1 0 , 0 0 0 , 0 0 0}$ \\
\hline Kenya & $36,730,000$ & $10,000,000$ \\
\hline South Europe & $\mathbf{2 4 0 , 0 0 0 , 0 0 0}$ & $\mathbf{6 5 , 3 4 1 , 6 8 3}$ \\
\hline Albania & $240,000,000$ & $65,341,683$ \\
\hline South Asia & $\mathbf{1 1 0 , 1 9 0 , 0 0 0}$ & $\mathbf{3 0 , 0 0 0 , 0 0 0}$ \\
\hline Bangladesh & $110,190,000$ & $30,000,000$ \\
\hline West Asia & $\mathbf{7 7 , 2 1 8 , 0 0 0}$ & $\mathbf{2 1 , 0 2 3 , 1 4 2}$ \\
\hline Palestine & $77,218,000$ & $21,023,142$ \\
\hline
\end{tabular}

${ }^{5}$ UAE Foreign AID. URL: https://www.mofa.gov.ae/EN/TheMinistry/UAEForeignPolicy/Pages/ UAEFAR.aspx (accessed 13.06.2018). 
End of the Table 5

\begin{tabular}{|c|c|c|}
\hline Region / Country & AED & USD \\
\hline Melanesia & $\mathbf{3 6 , 7 3 0 , 0 0 0}$ & $\mathbf{1 0 , 0 0 0 , 0 0 0}$ \\
\hline Vanuatu & $18,365,000$ & $5,000,000$ \\
\hline Fiji & $18,365,000$ & $5,000,000$ \\
\hline Polynesia & $\mathbf{3 6 , 7 3 0 , 0 0 0}$ & $\mathbf{1 0 , 0 0 0 , 0 0 0}$ \\
\hline Tuvalu & $18,365,000$ & $5,000,000$ \\
\hline Samoa & $18,365,000$ & $5,000,000$ \\
\hline Micronesia & $\mathbf{1 8 , 3 6 5 , 0 0 0}$ & $\mathbf{5 , 0 0 0 , 0 0 0}$ \\
\hline Kiribati & $18,365,000$ & $5,000,000$ \\
\hline Global & $\mathbf{1 8 , 3 6 5 , 0 0 0}$ & $\mathbf{5 , 0 0 0 , 0 0 0}$ \\
\hline Multi-region (Global) & $18,365,000$ & $5,000,000$ \\
\hline GRAND TOTAL & $\mathbf{2 9 , 1 3 5 , 9 4 3 , 3 0 0}$ & $\mathbf{7 , 9 3 2 , 4 6 4 , 8 2 4}$ \\
\hline
\end{tabular}

Source: UAE Foreign Aid Mini Report $2013^{6}$.

The AFESD is a major Middle-Eastern funding institution that seeks to achieve economic and social development across all the Arab countries. This is also to encourage further cooperation between member states of the Arab League. Although many countries in the region remain in need for support due to the political instabilities, the fund has relatively managed to fund many infrastructural projects and supported private sectors. According to the annual report of the AFESD, "infrastructure sectors accounted for about $93.0 \%$ of the total amount of loans provided during 2017, in light of priorities set in member countries' plans and programs that focused on improving these sectors, and providing an environment conducive to investment and employment opportunities" [Annual Report 2017]. Table below is an example of the AFESD activities.

Signed Loans as of 31/12/2017 (amounts, thousands KD)

Table 6

\begin{tabular}{|l|l|c|l|l|c|c|c|}
\hline No. & \multicolumn{1}{|c|}{ Name of Project } & $\begin{array}{c}\text { Loan } \\
\text { No. }\end{array}$ & \multicolumn{1}{|c|}{ Country } & Sector & $\begin{array}{c}\text { Original } \\
\text { Amount }\end{array}$ & $\begin{array}{c}\text { Cancelled } \\
\text { Amount }\end{array}$ & $\begin{array}{c}\text { Net } \\
\text { Amount }\end{array}$ \\
\hline 1 & $\begin{array}{l}\text { Development of Electric } \\
\text { Transmission Grid }\end{array}$ & 651 & Egypt & Energy & 60,000 & 0 & 60,000 \\
\hline 2 & $\begin{array}{l}\text { Reinforcement of Transport Of } \\
\text { Desalinated Water }\end{array}$ & 649 & Oman & $\begin{array}{l}\text { Water } \\
\text { and Sew }\end{array}$ & 60,000 & 0 & 60,000 \\
\hline 3 & Al-Salt Corridor Road Project & 648 & Jordan & Transport & 14,000 & 0 & 14,000 \\
\hline 4 & Tunis - Jelma Highway & 647 & Tunisia & Transport & 50,000 & 0 & 50,000 \\
\hline 5 & $\begin{array}{l}\text { Rehabilitation of Part of Road 32 } \\
\text { (Ind. Area - Duqm) }\end{array}$ & 646 & Oman & Transport & 52,000 & 0 & 52,000 \\
\hline 6 & $\begin{array}{l}\text { Electrical Interconnection } \\
\text { (Nouakchott / Zouerate) }\end{array}$ & 645 & Mauritania & Energy & 42,000 & 0 & 42,000 \\
\hline 7 & $\begin{array}{l}\text { Water Supply For Layoun, Jakni } \\
\text { \& Peripheral Towns }\end{array}$ & 644 & Mauritania & $\begin{array}{l}\text { Water } \\
\text { and Sew }\end{array}$ & 15,000 & 0 & 15,000 \\
\hline 8 & $\begin{array}{l}\text { Construction of Al-Bagair Power } \\
\text { Generating Station }\end{array}$ & 643 & Sudan & Energy & 52,000 & 0 & 52,000 \\
\hline 9 & $\begin{array}{l}\text { Irbid Corridor Road Project } \\
\text { (Phase I) }\end{array}$ & 642 & Jordan & Transport & 15,000 & 0 & 15,000 \\
\hline 10 & $\begin{array}{l}\text { Rehabilitation of Guelb Ind. } \\
\text { Unit (1) }\end{array}$ & 641 & Mauritania & $\begin{array}{l}\text { Industry } \\
\text { and Mining }\end{array}$ & 32,000 & 0 & 32,000 \\
\hline 11 & $\begin{array}{l}\text { Construction of Bridges on } \\
\text { Classified Roads }\end{array}$ & 640 & Tunisia & Transport & 20,000 & 0 & 20,000 \\
\hline 12 & $\begin{array}{l}\text { Photovoltaic Cells Electricity } \\
\text { Power Station }\end{array}$ & 638 & Egypt & Energy & 26,000 & 0 & 26,000 \\
\hline 13 & $\begin{array}{l}\text { Rehab. \& Strengthen Of Water } \\
\text { Distrib. Network in Djibouti City }\end{array}$ & 635 & Djibouti & $\begin{array}{l}\text { Water } \\
\text { and Sew }\end{array}$ & 20,000 & 0 & 20,000 \\
\hline TOTAL & & & 458,000 & 0 & 458,000 \\
\hline
\end{tabular}

Source: [Projects \& Operations 2017].

${ }^{6}$ UAE Foreign AID. URL: https://www.mofa.gov.ae/EN/TheMinistry/UAEForeignPolicy/Pages/ UAEFAR.aspx (accessed 13.06.2018). 
Nonetheless, the UAE and all other Arab donors have received criticism over the fact that the majority of their aid goes only to fellow Arab states. The focus on the Arab countries is sometimes perceived as being driven by more political objectives rather than just solidarity. According to Cotterrell and Harmer, "one of the difficulties of identifying, or relying on, solidarity is that these solidarities are not fixed and are subject to fluctuations over time which cannot be understood in isolation from the political context of the national societies and their donors" [Cotterrell, Harmer 2005]. It is believed that ideology and politics have mingled with the political economy of assistance. Sometimes aid from Arab donors is perceived as politics and sometimes as solidarity. However, this analysis is not always true and not all Arab donors have the same behaviour. It might be true that during particularly times political consideration played a role, yet solidarity became the main driving force. For the UAE, it is evident from its aid activities since 1980 's that many countries received aid with no any political or economic returns. According to the UAE report, "more than two-thirds of the UAE foreign assistance was directed to support developing countries in Africa from 2014-2016. Although countries in Asia received lesser in terms of proportion, UAE foreign aid disbursements to Asia increased by $13 \%$ in 2016 when compared with 2015" [UAE Foreign Aid... 2017]. This shows that there are many countries in Africa and Asia that are neither Arab nor Muslim background. This is also part of the UN Sustainable Development Goals where the UAE strongly proving itself as a responsible donor to achieve all of its goals.

Due to the fact that the UAE is located in a region that faces political and economic instabilities, it has priorities its aid to Arab countries. The reason is not only due to share identities, but due to the fact that political violence in the region and security threats in the region are absolutely transnational. Therefore, the UAE seeks to provide aid to support stabilities in the Middle East. Political interests certainly do exist, yet, the UAE work alongside other regional aid donors such as Saudi Arabia. Since the so-called Arab Spring, the amount of aid to the regional countries have increased dramatically, making for example Yemen the largest recipient of humanitarian aid, while in contrast Egypt is the largest of development aid. According to Isaac, "the cumulative development finance from the eight major Arab donors almost 60\% went to Arab countries" [Isaac 2014]. The objectives are two-fold: stability and economic development. In addition, while foreign aid donors such as the UAE expect no returns, foreign investment within the region increased dramatically as another tool of benefiting both donor and recipient. Isaac points out that "in 2009 financial year the GCC share of intra-MENA trade was the highest, accounting for $60 \%$ of exports and $48 \%$ of imports. Also, the Arab share in foreign populations in the GCC states was the highest during the 1970 's and the 1980 's, ranging from $72 \%$ to $56 \%$ respectively" [Isaac 2014].

Therefore, solidarity sometimes is intrinsically intertwined with other objectives. Sometimes regional dynamics forces the UAE to change its foreign aid behaviour to support political and economic stability in the region. Nonetheless, the provision of aid to many countries in the Global South that are not of Arab or Muslim background have grown significantly since 1980's, when the UAE expanded its geographical scope of aid to include more countries in need. Most Arab donors, particularly the Gulf, provide 
aid mainly bilaterally. However, the past years seen gradual increase of the UAE multilateral aid. In 2016, the UAE continued its support towards development and humanitarian programs with regional and global reach, disbursing 1.08 billion AED (293.5 million USD), largely through contributions to the core budget of several multilateral organizations [UAE Foreign Aid... 2017]. In addition, the UAE foreign aid report indicates that the UAE funding to these multi-country programs rose by $236 \%$ over 2015 . This significant growth is mostly due to an increase in disbursements towards support to the core budget of multilateral organizations $(+234 \%)$, to earmarked funding channelled through multilateral organizations $(+128 \%)$, and contributions to the work of international non-governmental organizations (+62\%) [UAE Foreign Aid... 2017]. The UAE is certainly heading towards more multilateral aid than bilateral, but this is still limited. The UAE foreign aid report of 2016 explains that "certainly a headway, the UAE disbursements in 2016 towards the core budget of multilateral organizations more than tripled when compared with 2015, while earmarked funding rose by $128 \%$ " [UAE Foreign Aid... 2017].

\section{CONCLUSION}

The UAE as an aid donor is becoming more visible than ever. Studies on 'emerging donors' indicated the importance of the rising role of donors from the Middle East such as the UAE. However, the UAE and other Gulf donors receive little attention that can explain their role in the South-South cooperation. Yet, not all the Gulf donors are the same. In fact, the UAE has developed its aid program, its reporting mechanism, aid institutions, its policies and strategies. This development led the UAE to engage with the UN and other governmental and non-governmental aid organizations to contribute to the development of countries in the Global South.

The hosting of SSC-Expo in 2016, creation of the National Committee for SSC, a dedicated portal, an annual report that follows how national and private aid agencies implement the SDGs reflects, to a great extent, the UAE engagement with the UN SDGs and SSC. In all the UAE foreign aid reports since 2013, implementing the SDGs is a major priority when giving aid. This stems from one main factor, solidarity, prior to the establishment of the Emirates, suffered from severe poor economic performance, poverty amongst its people, poor education, etc. This has transformed significantly after 1970's. It has experienced what many countries in the South are facing nowadays. This is a major motive for the UAE to ease the suffering of other countries, contribute to their economic development, education, health, etc.

Therefore, solidary is certainly a main driving force for the UAE to provide assistance to countries in the South. Nonetheless, the UAE with some other regional donors received criticism that their main activities are within the Arab world. The UAE is very much aware of its support and commitment to South-South development, however, regional political instabilities forced it to make some changes to its aid priorities. During the 1970's and last ten years, aid was clearly dictated by certain political and security objectives. The UAE sees this as part of its regional responsibility 
before giving aid to countries out side the Middle East and North Africa. The MENA region suffers from great economic downturns and political instabilities as well as rise of violent non-state actors that hinder economic development. Therefore, the UAE with other regional donors, aid contributed the development of some of the Arab countries.

The UAE humanitarian aid reflects its commitments to support the "Global South" and achieving some of the MDGs [Almezaini 2017]. Due to the political instabilities in the Middle East, the UAE has also been amongst the largest donors to refugees in the world [Almezaini 2017]. It has responded to the Syrian crisis, where it has provided, in 2012 and 2013, about 83.53 million USD [Almezaini 2017]. In 2013, the UAE opened the Emirates-Jordanian camp in Mrijib Al Fhood area near Al Zarqa city in a cost of 36 million AED (about 12 million USD) [Almezaini 2017]. By March 2015, the UAE's aid aimed at alleviating the suffering of those affected by the Syrian crisis has amounted to more than 1.34 billion AED or 364 million USD according to the Ministry of International Cooperation and Development [Almezaini 2017].

Overall, the UAE aid continues to rise at the regional and international levels targeting mainly countries in the Global South. Its aid constituted about $1.33 \%$ of its GDP in 2013, and has exceeded the target set by the UN which is $0.7 \%$ [Almezaini 2017]. Nonetheless, the UAE's regional responsibilities might be priority for many years to come due to the political instabilities. While countries the MENA are from the Global South, other counties in the world receive aid significantly, mainly for humanitarian purposes. The UAE is in fact one of the largest humanitarian donors in the world. According to Khaleej Times, "the UAE has been named the world's largest donor of development assistance in proportion to its gross national income (GNI) for the fifth year running, according to the Development Assistance Committee of the Organization of Economic Cooperation and Development (OECD)"'7 In addition, the UAE exceeded the UN target of $0.7 \%$ official development assistance in proportion to its GNI ratio by donating 19.32 billion AED, a growth of $18.1 \%$ over 2016, representing $1.31 \%$ of its GNI for official development assistance in $2017^{8}$.

\section{REFERENCES}

Almezaini, K. (2012). The UAE and Foreign Policy: Foreign Aid, Identities and Interests. Culture and Civilization in the Middle East. London: Routledge.

Almezaini, K. (2017). From Identities to Politics: UAE Foreign Aid. In: South-South Cooperation Beyond the Myths Rising Donors, New Aid Practices? Ed. by I. Bergamaschi, P. Moore and A.B. Tickner. London: Palgrave Macmillan, p. 225-244.

Al-Zayed, S. (2012). The Influence of Financial Kuwaiti Aid on Its Arab Relations. Amman: Middle East University.

Annual Report. (2017). Arab Fund for Economic and Social Development (AFESD). Kuwait: Arab Fund for Economic \& Social Development.

${ }^{7}$ Khaleej-Times. "Uae Named World's Largest Humanitarian Donor for Fifth Year", Khaleej times. URL: https://www.khaleejtimes.com/news/general/uae-named-worlds-largest-humanitariandonor-for-fifth-year- (accessed 13.06.2018).

8 Ibid. 
Cotterrell, L. \& Harmer, A. (2005). Aid Donorship in the Gulf States. Overseas Development Institute. HPG Background Paper (September 2005). London. URL: https://www.odi.org/sites/odi.org.uk/ files/odi-assets/publications-opinion-files/414.pdf (accessed 13.06.2018).

El Mallakh, R. \& Kadhim, M. (1976). Arab Institutionalized Development Aid: An Evaluation. Middle East Journal, 30 (4), 471-484.

Hunter, S.T. (1984). OPEC and the Third World: The Politics of Aid. London: Croom Helm.

Isaac, S.K. (2014). Explaining the Patterns of the Gulf Monarchies' Assistance after the Arab Uprisings. Mediterranean Politics, 19 (3), 413 - 430. DOI: https://doi.org/10.1080/13629395.2014.959759.

Law, J.D. (1978). Arab Aid: Who Gets It, for What, and How. Chase World Information Corporation.

Mertz, R.A. \& Mertz, P.M. (1983). Arab Aid to Sub-Saharan Africa. Wissenschaftliche Reihe 29. Grunewald: Kaiser.

Neumayer, E. (2003). What factors determine the allocation of aid by Arab countries and multilateral agencies? Journal of Development Studies, 39 (4), 134-147.

Nonneman, G. (1988). Development, Administration and Aid in the Middle East. London: Routledge.

Projects \& Operations. (2017). Arab Fund for Economic and Social Development (AFESD). Kuwait: Arab Fund for Economic and Social Development.

Purpose of the Fund. (2017). Arab Fund for Economic and Social Development (AFESD). URL: http://www.arabfund.org/Default.aspx?pageId=198 (accessed 13.06.2018).

Quadir, F. (2013). Rising Donors and the New Narrative of South-South Cooperation: What Prospects for Changing the Landscape of Development Assistance Programmes? Third World Quarterly, 34 (2), 321-338. DOI: https://doi.org/10.1080/01436597.2013.775788.

Rouis, M. (2010). Arab Development Assistance Four Decades of Cooperation. Washington, DC: World Bank.

Shihata, I.F.I. (1982). The Other Face of OPEC: Financial Assistance to the Third World. London; New York: Longman.

Shushan, D. \& Marcoux, C. (2011). The Rise (and Decline?) of Arab Aid: Generosity and Allocation in the Oil Era. World Development, 39 (11), 1969-1980. DOI: 10.1016/j.worlddev.2011.07.025.

South-South and Triangular Cooperation Solutions for Sustainable Development: United Arab Emirates. (2016). UNOSSC. NYC and Dubai: Zayed International Foundation for the Environment.

UAE Foreign Aid 2016. (2017). Ministry of Foreign Affairs and International Cooperation (MOFAIC). Abu Dhabi.

UAE and the 2030 Agenda for Sustainable Development. (2017). National Committee on Sustainable Development Goals (NCSDG). Abu Dhabi.

Van den Boogaerde, P. (1991). Financial Assistance from Arab Countries and Arab Regional Institutions. International Monetary Fund.

Received: 15.08 .2018

For citations: Almezaini, K. (2018). Implementing Global Strategy in the UAE Foreign Aid: from Arab Solidarity to South-South Cooperation. Vestnik RUDN. International Relations, 18 (3), 579-594. DOI: 10.22363/2313-0660-2018-18-3-579-594.

About the Author: Khalid Almezaini - Assistant Professor, Zayed University, UAE, Research Associate, the University of Cambridge, UK (e-mail: k.almezaini@gmail.com). 


\title{
К ГЛОБАЛЬНОЙ СТРАТЕГИИ МЕЖДУНАРОДНОЙ ПОМОЩИ ОАЭ: ОТ АРАБСКОЙ СОЛИДАРНОСТИ К СОТРУДНИЧЕСТВУ ЮГ-ЮГ
}

\author{
Х. Альмезаини \\ Университет Зайда, Абу-Даби, Объединенные Арабские Эмираты \\ Кембриджский университет, Кембридж, Великобритания
}

Статья посвящена феномену деятельности «новых доноров» в рамках сотрудничества ЮгЮг. Пример оказания международной помощи Объединенными Арабскими Эмиратами (ОАЭ) демонстрирует новые принципы и инструменты сотрудничества Юг-Юг; прежде всего, это солидарность и взаимодействие с ООН и другими правительственными и неправительственными организациями по оказанию помощи в целях содействия развитию стран «Глобального Юга». Положение ОАЭ на региональном (ближневосточном) и международном уровне обязывает страну к оказанию всех видов помощи, особенно гуманитарной. По сути, ОАЭ являются «гуманитарной нацией», где содействие развитию становится частью ежедневной внешнеполитической деятельности государства. Следовательно, отношения ОАЭ со странами Юга и так называемыми «развивающимися странами» стали развиваться в достаточно активном режиме, поскольку ОАЭ способствуют экономическому росту этих государств. Сотрудничество Юг-Юг включает в том числе обмен технологий и ресурсов между развивающимися странами.

Используя преимущественно количественную методологию, автор анализирует стратегию внешней помощи ОАЭ и подтверждает ее согласованность с Целями устойчивого развития и Целями развития тысячелетия, объявленными ООН. Более того, автор показывает расширение географии иностранной помощи ОАЭ: крупнейшими получателями помощи ОАЭ в основном являются государства Азии и Африки, где находятся самые бедные страны мира.

Ключевые слова: Объединенные Арабские Эмираты (ОАЭ), сотрудничество Юг-Юг, международная помощь, Ближний Восток, Цели устойчивого развития, Цели тысячелетия в области развития, межарабская помощь

Дата поступления статьи: 15.08.2018

Для цитирования: Almezaini $K$. Implementing Global Strategy in the UAE Foreign Aid: from Arab Solidarity to South-South Cooperation // Вестник Российского университета дружбы народов. Серия: Международные отношения. 2018. Т. 18. № 3. С. 579-594. DOI: 10.22363/23130660-2018-18-3-579-594.

Сведения об авторе: Халид Альмезаини - доцент Университета Зайда, Абу-Даби, ОАЭ; научный сотрудник Кембриджского университета, Великобритания (e-mail: k.almezaini@gmail.com).

(C) Khalid Almezaini, 2018 